\title{
EUROPEAN EFFORTS TO CONTROL THE SPREAD OF ENRICHMENT AND REPROCESSING TECHNOLOGIES
}

\author{
Oliver Meier ${ }^{1}$ \\ Institute for Peace Research and Security Policy (IFSH)
}

\begin{abstract}
:
EU efforts to foster agreement on better measures to prevent the misuse of uranium enrichment and plutonium reprocessing (ENR) technologies are an easy test for the effectiveness European policies to improve controls over proliferation-sensitive technologies more generally. Three examples of attempts to strengthen ENR controls are examined. EU members and the EU were actively engaged in efforts to peacefully resolve the conflict over Iran's nuclear program, in the strengthening of guidelines of the Nuclear Suppliers Groups for the trade in ENR technologies and in endeavours to develop multilateral approaches for enrichment and reprocessing facilities. Yet, European efforts suffered from the same lack of coherence that characterizes the EU's non-proliferation policies more generally. Realistically, it will be up to EU member states and particularly those with access to ENR technologies to provide political leadership on nuclear non-proliferation issues such as better ENR controls.
\end{abstract}

Keywords: European Union, nuclear non-proliferation, Nuclear Non-Proliferation Treaty, nuclear fuel cycle, uranium enrichment, Nuclear Suppliers Group, International Atomic Energy Agency.

\section{Resumen:}

Los esfuerzos de la Unión Europea por promover un acuerdo sobre mejores medidas para prevenir el abuso del enriquecimiento nuclear y de las tecnologías de reprocesamiento de plutonio (ENR en sus siglas en inglés) representan un fácil test para probar la efectividad de las politicas europeas para mejorar los controles sobre tecnología susceptible de proliferación. Aquí se examinarán tres ejemplos de intentos de reforzar controles sobre ENR. Los miembros de la UE y la UE misma han estado activamente implicados en los esfuerzos conducentes a la resolución pacífica del conflicto sobre el programa nuclear de Irán, en el reforzamiento de las directrices del Grupo de Suministradores Nucleares sobre exportación de tecnología de ENR y en los intentos para desarrollar un acercamiento multilateral para las instalaciones para el enriquecimiento y el reprocesamiento. Sin embargo, los esfuerzos europeos sufrieron de la misma falta de coherencia que caracteriza a las políticas de no proliferación de la UE en general. Dependerá de los miembros de la UE y en particular de aquellos con acceso a tecnologías de ENR el que se pueda suministrar liderazgo político sobre asuntos de no proliferación tales como un mejor control de ENR.

Palabras clave: Unión Europea, no proliferación nuclear, Tratado de No Proliferación Nuclear, ciclo de combustible nuclear, enriquecimiento de uranio, El Grupo de Suministradores Nucleares, La Agencia Internacional de la Energía Atómica.

\section{Copyright $@$ C UNISCI, 2012.}

Las opiniones expresadas en estos artículos son propias de sus autores, y no reflejan necesariamente la opinión de UNISCI. The views expressed in these articles are those of the authors, and do not necessarily reflect the views of UNISCI

\footnotetext{
${ }^{1}$ Dr. Oliver Meier is Senior Researcher at the Institute for Peace Research and Security Policy at the University of Hamburg and correspondent of the U.S. Arms Control Association.

E-mail: oliver.meier@ifsh.de.

http://dx.doi.org/10.5209/rev_UNIS.2012.n30.4070]
} 


\section{European Efforts to Control the Spread of Enrichment and Reprocessing Technologies}

Preventing the spread of nuclear, biological and chemical weapons of mass destruction (WMD) is a core objective of the EU. The European Security Strategy (ESS) states that the "[p]roliferation of [WMD] is potentially the greatest threat to our security." ${ }^{2}$ Likewise, the EU Strategy Against Proliferation of Weapons of Mass Destruction (WMD Strategy), which was adopted at the same time as the ESS in December 2003, says that the EU's objective is "to prevent, deter, halt and, where possible, eliminate proliferation programmes of concern worldwide. ${ }^{3}$

Non-proliferation is a complex challenge and the EU believes that it is "particularly well equipped to respond to such multi-faceted situations." "The WMD strategy argues that the EU "must act with resolve, using all instruments and policies at its disposal." 5 Thus, the EU promotes an active, capable and coherent strategy of effective multilateralism to tackle proliferation challenges and maintains that "[p]roliferation may be contained through export controls and attacked through political, economic and other pressures while the underlying political causes are also tackled." ${ }^{6}$ In 2003, the EU acknowledged that its foreign and security policy needs "to be more active, more coherent and more capable." Five years later the Union specifically states that "in the light of experience and new developments" its nonproliferation policies "must be identified in such a way as to increase the effectiveness and impact of the EU's approach and make it even more operational.",

Thus, the EU has begun to mainstream non-proliferation into its foreign relations in an attempt to use its economic power to achieve non-proliferation goals. ${ }^{9}$ While the EU has a preference for soft power, it acknowledges that when diplomatic and preventive measures have failed, "coercive measures under Chapter VII of the UN Charter and international law" could be envisioned to stem proliferation. ${ }^{10}$

Preventing the spread of nuclear weapons is the most important issue on the EU's nonproliferation agenda. In contrast to biological and chemical weapons, nuclear weapons are not universally prohibited and nuclear proliferation receives far more attention than the threat of biological or chemical weapons proliferation. Efforts to better control the spread of enrichment and reprocessing (ENR) technologies are a key element of any nuclear nonproliferation strategy. From the early days of the nuclear age, efforts to control ENR

\footnotetext{
${ }^{2}$ Council of the European Union: “A Secure Europe in a Better World: European Security Strategy”, Brussels, 12 December 2003, p. 4, at http://www.consilium.europa.eu/uedocs/cmsUpload/78367.pdf.

3 Council of the European Union: "EU strategy against proliferation of Weapons of Mass Destruction", (15708/03), Brussels, (12 December 2003), p. 2 at http://register.consilium.europa.eu/pdf/en/03/st15/st15708.en03.pdf.

${ }^{4}$ Council of the European Union, “A Secure Europe In A Better World...”, op. cit., p.7.

${ }^{5}$ Council of the European Union: "EU strategy against proliferation...", op. cit., p. 2.

${ }^{6}$ Council of the European Union: "European Security Strategy", p. 7.

${ }^{7}$ Ibid, p. 11.

${ }^{8}$ Council of the European Union: "New lines for action by the European Union in combating the proliferation of weapons of mass destruction and their delivery systems", (16089/08), Brussels, (23 November 2008), p. 3.

9 See Grip, Lina: "The EU Non-proliferation Clause: A Preliminary Assessment", SIPRI Background Paper, Stockholm, Stockholm International Peace Research Institute, (October 2009), at http://books.sipri.org/files/misc/SIPRIBP0911.pdf; Quille, Gerrard: “A New Transatlantic Approach? A View from Europe", in Daase, Christopher; Meier, Oliver (eds.): Arms control in the 21st century: Between coercion and cooperation, New York, Routledge forthcoming 2012.

${ }^{10}$ Council of the European Union: "EU strategy against proliferation...”, op.cit., p. 5.
} 
technologies - i.e. knowledge, materials or technology that can be used to enrich uranium or to separate plutonium - have been in the focus of non-proliferation because it is impossible to build a nuclear explosive device without enriched uranium or plutonium. This technical bottleneck therefore offers an attractive way to prevent the emergence of new nuclear weapon programs.

Yet, efforts to control ENR technologies face serious difficulties. Uranium enrichment and plutonium are inherently dual-use because they can also be used to produced fuel for nuclear power plants. Article IV of the nuclear Non-Proliferation Treaty (NPT), which states that nothing in the accord shall affect "the inalienable right" of states parties "to develop research, production and use of nuclear energy for peaceful purposes"11 also applies to ENR technologies. ${ }^{12}$ So far, all attempts to reach an international agreement under the NPT to further restrict the use or transfer of ENR technologies have failed. ${ }^{13}$ Another big challenge for efforts to prevent the spread of enrichment technologies is the emergence of black market networks. For example, Pakistani nuclear engineer A.Q. Khan has demonstrated that states that are not traditional technology holders have traded and could continue to trade sensitive nuclear technologies. ${ }^{14}$

Yet, a number of characteristics make it easier to control such technologies. Compared to other dual-use technologies, enrichment and reprocessing takes place in large facilities that are relatively easy to track. ${ }^{15}$ And the economic importance of ENR technologies is limited. Currently only a few providers in half a dozen countries provide international nuclear fuel services. Only France (Areva) and the United Kingdom (Sellafield Ltd) offer commercial reprocessing services ${ }^{16}$ and four companies divide the international market for commercial uranium enrichment services among themselves: Areva (formerly Eurodif Consortium, France), Tenex (Russia), Urenco (Germany, Netherlands, United Kingdom) and USEC (United States). The market for enrichment and reprocessing services is expected to expand but by how much will depend on the growth of global nuclear energy production.

European companies are major players on the enrichment market. In 2010, Urenco held about 22 percent of global enrichment capacity. ${ }^{17}$ Urenco's enrichment technology is considered to be the most advanced and the company is currently building additional plants in France and the United States. In 2011, Urenco's annual revenues were Euro 1.3 billion and the company generated an income of Euro 525 million. ${ }^{18}$ The revenues of Areva's front-end activities in 2011 were Euro 2.2 billion, about a third of these profits were made in the enrichment sector. ${ }^{19}$ Areva's revenues for back-end related activities in 2011 were Euro 1.6

\footnotetext{
${ }^{11}$ Treaty on the Non-Proliferation of Nuclear Weapons, Article IV.

12 See Joyner, Daniel (2011): Interpreting the Nuclear non-proliferation treaty, Oxford/New York, Oxford University Press.

${ }^{13}$ See for example Yudin, Yury (2010): Multilateralization of the Nuclear Fuel Cycle: The Need to Build Trust, Geneva, United Nations Institute for Disarmament Research.

${ }^{14}$ See for example Blackford, Jacob: "Multilateral Nuclear Export Controls after the A.Q. Khan Network", Washington, D.C., International Institute for Science and Security, (January 2005), at http://isisonline.org/uploads/isis-reports/documents/multilateralexportcontrols.pdf.

${ }^{15}$ For example, clandestine reprocessing activities could be traced from a distance because they emit distinctive radionuclides. See Kalinowski, Martin B.; Daerr, Heiner and Kohler, Markus: "Measurements of Krypton-85 to Detect Clandestine Plutonium Production”, INESAP Information Bulletin, No. 27 (December 2006), pp. 9-12.

${ }^{16}$ Other states that operate enrichment facilities are Brazil, China, India, Iran, Japan, Pakistan and possibly North Korea.

17 World Nuclear Association: "Uranium Enrichment", (updated 18 March 2012), at http://www.worldnuclear.org/info/inf28.html.

${ }^{18}$ Urenco: "Annual report and accounts 2011", p. 2, at http://www.urenco.com/content/69/publications.aspx.

${ }^{19}$ Areva Group: "Mining-Front End - a consolidated position among the leaders", at
} 
billion, of which reprocessing was responsible for about 60 percent. Yet, in comparison to other energy sectors, economic interests in the nuclear fuel market are relatively small. ${ }^{20}$

Because the stakes are high and the economic impact of more effective controls would be comparatively limited, fostering agreement on better measures to prevent the misuse of ENR technologies should be an easy test for the effectiveness of European policies to improve controls over proliferation-sensitive technologies more generally. Put another way: If the EU is not able to foster more effective controls for ENR technologies, it can hardly be expected to successfully tackle issues which receive less attention, where the verification challenges are more difficult and the impact on economic interests larger.

Against this background, this article provides a cursory review of European efforts to better control ENR technologies. What factors have been driving the EU's position on the control of ENR technologies? Has the EU been effective in fostering international agreement on a common approach to preventing the spread of ENR technologies? It looks at the issue from the perspectives of bilateral, plurilateral and multilateral efforts of the EU by summarizing European policies to control the spread of ENR technologies in the context of

- Negotiations about a peaceful solution of the Iranian nuclear crisis,

- The debate about new guidelines in the Nuclear Suppliers Group (NSG) and

- $\quad$ The discussion on multilateral nuclear approaches (MNA).

These three cases are with a view to evaluate the EU's own benchmarks for an effective nonproliferation policy, i.e. that the European foreign and security policy needs to be active, coherent and capable. Since these are soft and subjective factors that defy systematic evaluation, the approach chosen here is to simply recount these episodes against the background of the EU's own ambitions. In conclusion, some features of the EU's approach to controlling ENR technologies are described.

\section{European Efforts to Limit Iran's Enrichment Capacities}

Efforts to find a diplomatic resolution to the Iranian nuclear crisis are the most ambitious and visible example of European attempts to prevent the misuse of ENR technology by a third state. Because the European engagement began in 2003, parallel to agreement on the ESS, Iran was often seen as the first test of the EU's ability to solve an important non-proliferation issue. ${ }^{21}$ At the core of Western policies to stop Iran from going nuclear was the attempt to restrict Iranian enrichment and reprocessing capacities. These were seen by the international community as the most important elements of the Iranian effort to achieve a nuclear weapons capability. Because Iran's plutonium-related activities (including the heavy-water reactor in Arak and associated reprocessing capabilities) are further away from becoming operational, curtailing enrichment was at the centre of international attention and European attempts to diffuse the Iranian nuclear crisis.

\footnotetext{
http://www.areva.com/EN/group-1886/the-front-end-division-consolidates-its-position-among-the-leaders.html.

${ }^{20}$ By comparison, the 2011 comprehensive income of British Petroleum alone was US\$21 billion, more than three times the total income generated by Areva's and Urenco's combined nuclear fuel services. See British Petroleum, "Summary Review 2011", at http://bp.com/summaryreview.

${ }^{21}$ See Meier, Oliver; Quille, Gerrard: "Testing Time for Europe's Nonproliferation Strategy", Arms Control Today, vol. 35, no. 4 (May 2005), pp. 4-12, at http://www.armscontrol.org/act/2005 05/Oliver_Quille.
} 
EU efforts to persuade Iran to forego enrichment and reprocessing can be divided into three phases. During the first phase, which lasted from October 2003 until 2005, the EU was deeply involved in a direct dialogue with Iran. These endeavours were viewed with scepticism by the George W. Bush administration, which had placed Iran in early 2002 on the "axis of evil." The release of information about Iran's nuclear enrichment facilities, heavy water reactor and other clandestine facilities in August $2002^{22}$ appeared to confirm Washington's assessment that Tehran "aggressively pursues" WMD. ${ }^{23}$ The EU's attempts to engage did not sit well with Washington's policy of isolating Iran, Iraq and North Korea. The Bush administration only grudgingly accepted the EU's lead in direct talks with Tehran.

Yet, Europeans perceived the dispute about Iran's nuclear program as an opportunity to heal some of the wounds that the U.S.-led invasion of Iraq in 2003 had created among Europeans. Here, Europe could demonstrate its ability to act together and prevent the military escalation of another crisis triggered by the spectre of WMD proliferation.

Ignoring U.S. concerns, British, French and German officials in October 2003 went to Tehran and engaged Iran in a direct dialogue. ${ }^{24}$ As a result of that meeting, Tehran agreed to suspend the enrichment of uranium and in December signed and later implemented an Additional Protocol which enabled the International Atomic Energy Agency (IAEA) to look for undeclared nuclear activities. The biggest success of the so-called EU3 was the 14 November 2004 Paris Agreement which expanded the moratorium to all ENR-related activities and extended it, as a confidence-building measure, for the time of negotiations. ${ }^{25}$ In retrospect, it is intriguing that according to the IAEA and U.S. intelligence agencies, Iran in 2003 stopped most if not all of its clandestine activities to "weaponize" fissile material, though the causal link to talks with the EU is not clear. ${ }^{26}$

From an internal EU perspective, the EU3 engagement of Iran was remarkable because the British, French and German initiative "met with few suspicions and with no significant resistance within the EU." 27 With conclusion of the Paris agreement, the EU3 were also officially acting with the support of the High Representative of the European Union (EU3/EU), which increased the involvement of other EU members. Yet, even though Berlin, London and Paris basically remained in charge of the Iranian nuclear file, "[t]he spectre of a Directoire leading the EU's foreign and security policy did not raise its head, confirming a tacit agreement that something had to be done to avoid a new European imbroglio à la Iraq." 28

\footnotetext{
${ }^{22}$ Jafarzadeh, Alireza: “New Information on Top Secret Projects of the Iranian Regime's Nuclear Program”, U.S. Representative Office, National Council of Resistance of Iran, (14 August 2002), at http://www.iranwatch.org/privateviews/NCRI/perspex-ncri-topsecretprojects-081402.htm.

${ }^{23}$ Bush, George W.: "The President's State of the Union Address", Washington, D.C., (29 January 2002), at http://georgewbush-whitehouse.archives.gov/news/releases/2002/01/print/20020129-11.html.

24 Portela, Clara (2003): The Role of the EU in the non-proliferation of nuclear weapons: The way to Thessaloniki and beyond, Frankfurt am Main: Peace Research Institute Frankfurt, pp. 17-19.

${ }^{25}$ IAEA: "Communication dated 26 November 2004 received from the Permanent Representatives of France, Germany, the Islamic Republic of Iran and the United Kingdom concerning the agreement signed in Paris on 15 November 2004", (INFCIRC/637), Vienna: International Atomic Energy Agency at http://www.nuclearfiles.org/menu/key-issues/nuclear-weapons/issues/proliferation/iran/eu-iran-nuclearagreement.htm.

${ }^{26}$ See for example Thielmann, Greg; Loehrke, Benjamin: “The IAEA's November Report on Iran: More Confirmation than Revelation", Iran Nuclear Brief, Washington, D.C., Arms Control Association, 5 December 2011.

${ }^{27}$ Van Ham, Peter: "The European Union's WMD Strategy and the CFSP: A Critical Analysis", EU NonProliferation Consortium, Non-Proliferation Papers, no. 2, (September 2011), p. 11 at http://www.nonproliferation.eu/documents/nonproliferationpapers/02 vanham.pdf. ${ }^{28}$ Ibid.
} 
During this period, the EU offered several incentives to Iran and requested a suspension of Iran's ENR-related activities as well as a clarification of outstanding questions about suspicious nuclear activities. In their most comprehensive offer, presented to Iran in August $2005,{ }^{29}$ the EU3 offered among other things the assured supply of low enriched uranium for light water reactors and proposed to established a nuclear fuel reserve in a third country. In return, the EU demanded binding commitments by Iran "not to pursue fuel cycle activities other than the construction and operation of light water power and research reactors" and an obligation not to withdraw from the NPT. These commitments were to be reviewed every ten years. ${ }^{30}$ Tehran rejected this offer because the EU3 did not recognise Iran's right to enrich uranium.

This impasse marked the beginning of the second phase of the EU's efforts to prevent Iran from closing the fuel cycle, which lasted from 2005-2006 until the end of 2008. During this period, Washington moved closer to the EU position. At the same time, after the election of Mahmoud Ahmadinejad as new President in June 2005, Iran began to disengage from talks with the EU. In August 2005, Iran resumed uranium conversion activities and in early 2006, it also restarted uranium enrichment at Natanz. For all practical purposes, the moratorium was dead.

Europeans reacted to this disengagement by supporting coercive measures against Iran. In September 2005, the EU members voted for a resolution in the IAEA Board of Governors that found Iran in non-compliance with its safeguards obligations and stated that Iran's nuclear activities "have given rise to questions that are within the competence of the Security Council." ${ }^{31}$ This meant that the threat of sanctions against Iran was imminent. Iran subsequently refused to negotiate with the EU3. The EU3/EU conceded that their negotiations with Iran had reached an impasse and on 30 January the Foreign Ministers of the EU3/EU as well as China, Russia and the United States declared their intention to inform the United Nations Security Council (UNSC) of their position on Iran's nuclear program. ${ }^{32}$

The EU's efforts to mediate now became part of activities undertaken by the five permanent members of the UNSC and Germany. On 1 June 2006, the P5+1 (or the EU3/EU+3 as European diplomats prefer to say) offered a new package to Iran, which included a range of economic incentives and raised the possibility of Iran's "participation as a partner in an international facility in Russia to provide enrichment services for a reliable supply of fuel to Iran's nuclear reactors."33 This was the first time that the United States endorsed such a proposal - a success for the EU's efforts to convince the George W. Bush administration of its approach of engagement. From now on, the EU was no longer merely acting as an intermediary between two reluctant partners. Yet, Iran did not respond to these

\footnotetext{
${ }^{29}$ IAEA: "Communication dated 8 August 2005 received from the Resident Representatives of France, Germany and the United Kingdom to the Agency" (INFCIRC/651), Vienna: International Atomic Energy Agency, (8 August 2005), at http://www.armscontrol.org/pdf/20050805 Iran_EU3 Proposal.pdf.

${ }^{30}$ Ibid.

${ }^{31}$ IAEA: "Implementation of the NPT Safeguards Agreement in the Islamic Republic of Iran - Resolution", (GOV/2005/77), Vienna: International Atomic Energy Agency Board of Governors Resolution, (24 September 2005), operational paragraph 2.

32 "Erklärung der Außenminister der E3/EU sowie Chinas, Russlands und der USA zu Iran", London, (30 January 2006), at http://www.auswaertiges-amt.de/cae/servlet/contentblob/337704/publicationFile/3434/E3EUCHN-RUS-USA-300106.pdf.

33 "Elements of a proposal to Iran as approved on 1 June 2006 at the meeting in Vienna of China, France, Germany, the Russian Federation, the United Kingdom, the Unites States of America and the European Union", at http://www.consilium.europa.eu/ueDocs/cms_Data/docs/presdata/en/reports/90569.pdf.
} 
offers and the EU eventually supported four resolutions in the UNSC that imposed various sanctions on Iran. ${ }^{34}$

During the third phase, which began with the change of administration in the United States in early 2009, European efforts to promote a diplomatic solution of the nuclear crisis with Iran lost focus and drive. There are multiple reasons for this development but most importantly, Europe was no longer needed as a mediator between hardliners in Washington and Tehran.

The Obama administration initially tried a new approach and used more conciliatory rhetoric toward Iran, including the offer of direct talks. Europeans wholeheartedly supported this policy. ${ }^{35}$ Yet, U.S. overtures were not reciprocated by Iran, partly because of divisions within the Iranian elite about the right approach toward the West and the United States specifically. The emergence of the opposition movement in Iran after the June 2009 Presidential elections further complicated the nuclear dialogue. Things came to head when Iran in July 2009 argued that the EU had "lost its qualification to hold nuclear talks" because of alleged interference in the protests against the re-election of President Ahmadinejad. ${ }^{36}$ The announcement in September 2009 by France, the United Kingdom and the United States that a previously undeclared enrichment facilities had been discovered in Iran further complicated diplomatic efforts. ${ }^{37}$

The Obama administration subsequently reverted to a tough policy vis-à-vis Iran. This time, the United States had the complete support of Europeans. The convergence between U.S. and EU policies was further reinforced by hardening stance of France which became an advocate for isolating Iran, moving away from the EU's previous preference for engagement. But diplomats from other European capitals and Brussels also were frustrated with Iran's perceived inability (or unwillingness) to pursue constructive and coherent negotiations.

Another complicating factor were institutional changes in the EU's Common Foreign and Security Policy as a result of the implementation of the Lisbon treaty. ${ }^{38}$ The EU's High Representative for Common Foreign and Security Policy, Javier Solana and his personal representative for the non-proliferation of WMD, Annalisa Giannella, had had a strong profile on Iran since 2003. The focus and continuity they had provided on non-proliferation issues, and specifically Iran, were lost to some degree when the EU's new External Action Service was set up. The EU's new high representative Catherine Ashton initially was unable to provide similar leadership, though there appear to be indications that Ashton has recently has improved her performance in dealing with Iran. ${ }^{39}$

As the EU's profile on the Iranian nuclear file became less visible, others attempted to fill the void. In February 2010, Iran began raising the level of enrichment to 20 percent and

\footnotetext{
${ }^{34}$ These are UNSC resolutions 1737 (2006), 1747 (2007), 1803 (2008) and 1929 (2010). For an overview see the website of the UNSC Iran sanctions committee, at http://www.un.org/sc/committees/1737/.

${ }^{35}$ Crail, Peter: "U.S. Still Committed to Engaging Iran", Arms Control Today, (July/August 2009), at http://www.armscontrol.org/act/2009 07-08/Iran.

${ }^{36}$ Blitz; James: “Interference rules EU out of nuclear talks, says Iran”, Financial Times, 2 July 2009.

${ }^{37}$ Crail, Peter: "Secret Iranian Enrichment Facility Revealed", Arms Control Today, (October 2009), at http://www.armscontrol.org/act/2009_10/Iran.

${ }^{38}$ See Grip, Lina: "Mapping the European Union's institutional actors related to WMD non-proliferation", NonProliferation Papers, EU Non-Proliferation Consortium, (May 2011), at http://www.nonproliferation.eu/documents/nonproliferationpapers/01_grip.pdf.

${ }^{39}$ Rozen, Laura: "How Iran Talks Were Saved From Verge of Collapse", Al-Monitor, 16 April 2012.
} 
justified the action by the need to fuel the Tehran Research Reactor (TRR). ${ }^{40}$ Over the course of the year, first the United States and then Brazil and Turkey tried to broker a deal under which Tehran that would be provided ready-made fuel for the TRR and in return would restrict its those activities aimed at 20 percent enrichment. The deal fell through for various reasons but it is noteworthy that the EU3/EU appeared to be unable to drive the issue forward, even though France is one of a few countries that have the technical ability to produce 20 percent-enriched fuel suitable for the TRR. ${ }^{41}$

Subsequently, the EU policy toughened further and in January 2012 the EU for the first time decided to apply sanctions against Iran that went beyond what was required under the UNSC resolutions. ${ }^{42}$

European negotiations with Iran have demonstrated the EU's ability to maintain a coherent position despite strong outside pressures. The George W. Bush administration had been trying to push the EU towards a tougher stand vis-à-vis Iran since the beginning of the talks with Tehran in 2003. Iran, on the other hand, has been trying to lure the EU away from the United States, arguing that UN Security Council referral and the possibility of sanctions would only escalate the crisis further. Even though there are substantial differences between member states on the right approach towards Iran, the EU so far has acted in a united manner. After the Iraq experience, this in itself is important progress, though it is unlikely that the model of the three largest EU states as well as the High Representative acting de facto on behalf of all EU members, will ever be repeated.

\section{European Efforts to Strengthen NSG Guidelines on Trade in ENR Technologies}

Effective export controls are a key objective of the EU's non-proliferation efforts. Many of the activities described in the 2008 New Lines of Action document, which updates the 2003 WMD Strategy, are related to strengthened trade controls. ${ }^{43}$ Such controls are harmonized among major suppliers in export control regimes such as the Australia Group (in which 40 countries agree on joint rules for the trade in chemical and biological dual-use technologies) and the Nuclear Suppliers Group (NSG, in which 46 participating states harmonize rules for the trade in nuclear technologies). Under the single economic market, the same export control regulations need to apply in all EU member states and the EU has a unified legislation (in the form of an EU Council Regulation) on the export of dual-use goods. ${ }^{44}$ Economic integration makes it necessary that all EU members participate in export control regimes. Thus, even though "[s]everal EU member states neither supply items contained in the NSG control lists

\footnotetext{
${ }^{40}$ Fissile material enriched to 20 percent uranium is used in the TRR but can also more easily be converted to weapons-grade material than material enriched to a level of 5 percent.

41 See Fitzpatrick, Mark: "Containing the Iranian Nuclear Crisis: The Useful Precedent of a Fuel Swap", Perceptions, vol. 16, no. 2 (Summer 2011), pp. 27-42.

${ }^{42}$ On 23 January 2012, the EU's Foreign Affairs Council inter alia decided to impose an import ban on Iranian crude oil and freeze the assets of the Iranian central bank within the EU. See Council of the European Union: "Council Decision 2012/35/CFSP of 23 January 2012 amending Decision 2010/413/CFSP concerning restrictive measures against Iran”, Brussels, 23 January 2012.

${ }^{43}$ Council of the European Union: "New lines for action by the European Union in combating the proliferation of weapons of mass destruction and their delivery systems", (16089/08), Brussels, 23 November 2008.

${ }^{44}$ Council of the European Union: "Council Regulation (EC) No 428/2009 of 5 May 2009 setting up a Community regime for the control of exports, transfer, brokering and transit of dual-use items", Brussels, (5 May 2009), at http://eur-lex.europa.eu/LexUriServ/LexUriServ.do?uri=OJ:L:2009:134:0001:0269:EN:PDF.
} 
nor act as significant transit points" 45 all EU members participate in the group. There are no regional groupings within the NSG and the EU does not formally coordinate its policies within export control regimes.

As an export-oriented bloc, the EU has a strong interest to minimize the impact of export control regulations on international trade. The EU's long-standing support for strengthened guidelines for exports of enrichment and reprocessing technologies is consistent with this goal because international trade in these technologies is limited. In recent years, there have only been six legal and overt transfers of ENR technologies and all of them have taken place between states that already operate such facilities. European nuclear fuel-service providers Areva and Urenco were involved in four of these deals. ${ }^{46}$

U.S. President George W. Bush's February 2004 proposal that NSG participants "should refuse to sell enrichment and reprocessing equipment and technologies to any state that does not already possess full-scale, functioning enrichment and reprocessing plant" triggered a new discussion on controls for ENR technologies. The proposal was strongly resisted by many NSG participants. Partly because of the upcoming 2005 NPT review conference they were "reluctant to enact any measure that might be construed as widening the divide between nuclear 'haves' and 'have-nots'.,"48

EU members agreed with Washington that the old NSG guidelines, which simply maintained that "[s]uppliers should exercise restraint in the transfer of sensitive facilities, technology and material usable for nuclear weapons or other explosive devices" were insufficient. ${ }^{49}$ But Europeans - like most other members of the NSG - deemed the Bush proposal to be too strict, inflexible and unfair.

Several EU members thus tried to identify and support alternative approaches to better control the trade in ENR technologies that were deemed more likely to get international support. One key aspect was that new guidelines should not be viewed as discriminatory. Emerging economies such as Argentina, Brazil and South Africa made clear that they would support an international agreement only if new controls would not prevent new states from closing the nuclear fuel-cycle. But developing countries were not alone in demanding a more equitable approach. Some European countries, such as Spain and Switzerland, also expressed concerns that new guidelines could impose additional restrictions on their access to enrichment technology, for example, if they one day wished to join Urenco. ${ }^{50}$

\footnotetext{
${ }^{45}$ Anthony, Ian; Ahlström, Christer; Fedchenko, Vitaly (2007): Reforming nuclear export controls: The future of the Nuclear Suppliers Group, SIPRI research report, 22, Oxford, Oxford University Press, p. 28.

${ }^{46}$ McGoldrick, Fred: "Limiting Transfer of Enrichment and Reprocessing Technology: Issues, Constraints, Options", Project on Managing the Atom, Cambridge, Massachusetts, Belfer Center for Science and International Affairs, Harvard Kennedy School, May 2011, pp. 9-10, at http://belfercenter.ksg.harvard.edu/files/MTA-NSG-report-color.pdf.

${ }^{47}$ George W. Bush: "Remarks by the President on Weapons of Mass Destruction Proliferation", Fort Lesley J. McNair - National Defense University, Washington, D.C., 11 February 2004.

${ }^{48}$ See Boese, Wade: "Nuclear Suppliers Pass on U.S. Proposals", Arms Control Today, (July/Aug. 2004), at http://www.armscontrol.org/act/2004_07-08/NSG.

49 IAEA: "Communications Received from Certain Member States Regarding Guidelines for the Export of Nuclear Material, Equipment and Technology", (INFCIRC/254/Rev.8/Part 1), Vienna, International Atomic Energy Agency, 20 March 2006, Article 6.

${ }^{50}$ Horner, Daniel: "Accord on New Rules Eludes Nuclear Suppliers", Arms Control Today, (July/Aug. 2009), at http://www.armscontrol.org/node/3729. See also McGoldrick, "Limiting Transfer of Enrichment...”, op. cit., p. 20.
} 
To counter the Bush administration's proposal, EU members promoted a criteria-based approach that would apply the same yardstick when deciding whether a state would be eligible to receive ENR technology. Discussions among EU members and within the NSG centred on which criteria should be applied for exports of ENR-related technologies. Some were of the opinion that only objective factors, such as membership in relevant international treaties, should be applied. Others wanted subjective criteria, such as whether the recipient was in a stable region, to also be taken into account.

France took the lead for the Europeans within the NSG. In 2004 it proposed a set of minimum criteria for ENR transfers, including factors such as whether a recipient

- Was a party to and in compliance with the NPT as well as safeguards commitments,

- Implements an Additional Protocol and

- Fulfills obligations under UNSC Resolution $1540 .^{51}$

According to the French proposal, recipient states would also have to conclude an agreement with the supplier state on assurances regarding non-explosive use of technologies supplied, guarantee the application of effective safeguards in perpetuity and have to apply international safety and security standards. ${ }^{52}$

A few months later, Canada introduced its own proposal for a criteria-based approach, which listed a set of objective criteria any recipient of ENR technologies would have to fulfil and also contained some subjective criteria, which the exporter could apply voluntary. This set of criteria subsequently became the basis for NSG discussions. ${ }^{53}$

Initially, the United States rejected a criteria-based approach and continued to insist on the approach contained in President Bush's 2004 speech. In April 2008, however, Washington began to also support a criteria-based approach. ${ }^{54}$ This was done partly to allay domestic concerns over the implications of the intended lifting of nuclear trade restrictions against India. In the heated debate in 2008 over the U.S.-India deal, then-Secretary of State Condoleezza Rice acknowledged concerns in U.S. Congress about the lack of guidelines ENR transfers and promised that the United States would make its "highest priority" to achieve an NSG decision to prohibit the export of ENR technology to states that are not party to the NPT. ${ }^{55}$

Yet, certain EU members rejected some of the additional criteria subsequently proposed by the United States because they viewed them as being too subjective. For example, the

\footnotetext{
51 See Boese, Wade: "Nuclear Export Criteria Lacks Consensus", Arms Control Today, (June 2008), at http://www.armscontrol.org/act/2008_06/NuclearExport. UNSC Resolution 1540 has the purpose to prevent the spread of WMD, their means of delivery and related technology to non-state actors, and it obliges all states not to support non-state actors that attempt to acquire such technologies. See United Nations Security Council: "UNSC Resolution 1540”, (S/Res/1540 (2004)), New York, 28 April 2004.

${ }^{52}$ McGoldrick, "Limiting Transfer of Enrichment...", op. cit., p. 13.

53 See Boese, Wade: "No Consensus on Nuclear Supply Rules", Arms Control Today, (Sept. 2005), at http://www.armscontrol.org/act/2005_09/NoConsensusNukeSupply.

${ }^{54}$ See Boese, Wade: “U.S. Joins Others Seeking Nuclear Export Criteria”, Arms Control Today, (May 2008), at http://www.armscontrol.org/act/2008 05/NuclearExport; McGoldrick, "Limiting Transfer of Enrichment...", op. cit., p. 14.

55 Kimball, Daryl: "Unfinished Business for the NSG", Arms Control Today, (October 2008), at http://www.armscontrol.org/act/2008_10/focus.
} 
Netherlands objected to the U.S. proposal that exporters should take into consideration whether exports of sensitive nuclear technology could stimulate others to seek similar technology. The Dutch argued that NPT members in good standing should not be denied access to nuclear technology. ${ }^{56}$

In November 2008, the NSG drafted a so-called "clean text" that contained a number of objective criteria that NSG participants should apply when authorizing the export of ENR technologies. Exporters were also encouraged to "exercise vigilance" and take subjective factors into account such as whether transfers are intended for peaceful purposes, whether there is a coherent rationale for seeking ENR technologies and whether the impact would have a destabilizing effect on regional security. ${ }^{57}$ Because of objections to these subjective criteria by some non-EU members, the NSG was unable to agree on the agreed text. ${ }^{58}$

Discussions on new guidelines for ENR technologies became entangled with the U.S. goal of granting an exception for India from NSG guidelines. The nuclear deal's "inherent logic of distinguishing between 'good' and 'bad' nuclear weapon states [was] damaging other states' efforts to develop a consistent approach towards proliferation and proliferators." 59 This particularly applied to the EU, whose policy of effective multilateralism after all was a reaction to the George W. Bush's selective approach to international politics.

Some Europeans therefore only reluctantly voted for the lifting of nuclear trade restrictions against India at the NSG's August 2008 plenary meeting. ${ }^{60}$ Some would have liked to see additional restrictions placed on India's nuclear program place, including on possible exports of ENR technologies. Yet, both the United States and India pressed for - and eventually got - a clean exemption for India from NSG guidelines.

Discussions on strengthened NSG guidelines for ENR exports continued. Delhi now began lobbying NSG members, and specifically EU members with large economic interests in India such as France and Germany, against making NPT membership a condition for supply of ENR technologies. ${ }^{61}$ India, which is not an NPT-member, feared that the clean exemption it received in 2008 from NSG guidelines would be undercut by such a condition.

When NSG failed to adopt the 2008 clean text, Europeans supported interim solutions. The members of the Group of Eight (G-8) industrialized countries agreed at their 2009 summit meeting to adopt the 2008 NSG text as a national policy for a year. ${ }^{62}$ This decision was extended for another year at the 2010 G8 summit, with the support of EU members Germany, France, Italy and the United Kingdom. Yet, the EU remained committed to the goal

\footnotetext{
${ }^{56}$ McGoldrick, "Limiting Transfer of Enrichment...”, op. cit., p. 15.

${ }^{57}$ The Clean Text is reproduced in McGoldrick, "Limiting Transfer of Enrichment...", op. cit., pp. 61-63.

${ }^{58}$ Turkey for example objected to regional stability being listed as a factor to be taken into consideration because it is situated near the Middle East. See ibid., pp. 16-17.

59 Quille, Gerrard: "The EU's approach to tackling the proliferation of Materials and Weapons of Mass Destruction and prospects for cooperation on the eve of the new US Administration", Working Paper, Brussels, European Parliament, Directorate-General for External Policies of the Union Directorate B - Policy Department, (5 November 2008), p. 12. Quille makes this argument to describe how the US-India has hurt EU efforts to promote a non-proliferation clause in trade and cooperation agreements but the arguments also applies to other issues.

${ }^{60}$ Austria was apparently among those countries that offered last minute amendments. See Boese, Wade: "U.S.Indian Nuclear Deal Reaches NSG Brink", Arms Control Today, (September 2008), at http://www.armscontrol.org/act/2008 09/USIndia.

${ }^{61}$ McGoldrick, "Limiting Transfer of Enrichment...", op. cit., p. 17

${ }^{62}$ See Horner, Daniel: "U.S. Official Mulls Ending NSG Rule Revamp”, Arms Control Today, (November 2010) at http://www.armscontrol.org/act/2010_11/NSGRevamp.
} 
of strengthening NSG guidelines and in its joint position for the 2010 NPT review conference vowed to promote early agreement on "the strengthening of the NSG guidelines, in particular on strengthened export controls on enrichment and reprocessing technologies.",63

In July 2011, seven years after George W. Bush triggered the debate on tougher rules for the trade in ENR technologies, the NSG finally did agree on a new set of guidelines. The agreement was in line with EU goal of having a subjective list of criteria. Thus, NSG participants agreed that they should "authorise the transfer of enrichment and reprocessing facilities, and equipment and technology therefor" only if the recipient

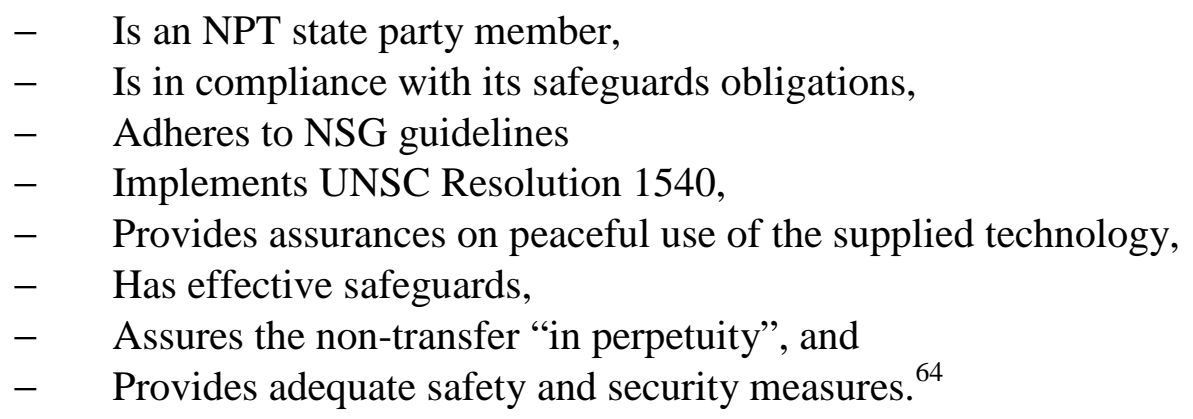

When they supported the adoption of the new guidelines, EU members ignored strong Indian objections. Indian officials argued that the new ENR guidelines "dilute the ... exemption that was given in $2008^{\prime 65}$ because they make NPT membership a condition of supply. It is ironic that France, which had initially taken the lead among Europeans in discussions on new guidelines for the transfers of ENR technologies, was also the first country to argue that the NSG decision to strengthen ENR guidelines "in no way undermines the parameters of" French-Indian nuclear cooperation. French Ambassador to India, Jérôme Bonnafont, said "[c]oming after the decision of exemption from the full-scope safeguards clause, adopted in favour of India in September 2008, it does not undermine the principles of this exemption." 66 At the time, Paris was in the process of selling nuclear technology to India and is also hoping to export 126 Rafale fighter jets, worth $\$ 11$ billion, to India.

\section{Multilateralizing Sensitive Nuclear Technologies}

As already discussed, U.S. President George W. Bush's February 2004 proposal that only those state that already possess full-scale, functioning enrichment and reprocessing plants

\footnotetext{
${ }^{63}$ Council of the European Union: “Council Decision 2010/212/CFSP of 29 March 2010 relating to the position of the European Union for the 2010 Review Conference of the Parties to the Treaty on the Non-Proliferation of Nuclear Weapons", Brussels, (29 March 2010), paragraph 46.

${ }^{64}$ IAEA: "Communication Received from the Permanent Mission of the Netherlands regarding Certain Member States' Guidelines for the Export of Nuclear Material, Equipment and Technology: INFCIRC/254/Rev.10/Part 1.", Vienna, International Atomic Energy Agency, (26 July 2011), pp. 1-2; see also Hibbs, Mark: "New Global Rules for Sensitive Nuclear Trade", Nuclear Energy Brief, Washington, D.C., Carnegie Endowment for International Peace, (28 July 2011), at http://carnegieendowment.org/2011/07/28/new-global-rules-for-sensitivenuclear-trade/4avp.

${ }^{65}$ Quoted in Varadarajan, Siddharth: "NSG ends India's 'clean' waiver", Reality, one bite at a time, 25 June 2011.

${ }^{66}$ Quoted in Dikshit, Sandeep: "In post-NSG statement, France ducks ENR ban on India", The Hindu, 2 July 2012 .
} 
should have access to ENR technology was seen by many developing countries as being incompatible with Article IV of the NPT. Some Europeans also viewed the Bush proposal with reservations because they feared that it could undermine efforts to strengthen the NPT by increasing the political divide among NSG members and those non-aligned states that were critical of efforts to further strengthen supply-side mechanisms. Those Europeans that did not have access to ENR technologies also feared that they might be "cut off" from sensitive nuclear technologies if Bush's proposals would be adopted. Others argued that such a proposal would not be compatible with the EU's principles of free trade. ${ }^{67}$ Generally speaking, Europeans therefore were interested in defining the middle ground between Washington's supply-side oriented approach and the principled position of the non-aligned states who called for unrestricted access to all nuclear technologies.

Proposals to multilateralize fuel-cycle activities were seen as an essential element of such a strategy of building a broader consensus for restrictions on access to and use of ENR technologies. In a nutshell, these multilateral nuclear assurances (MNAs) aimed at offering states that were considering building new enrichment or reprocessing facilities assurances of nuclear fuel supply. Such assurances, which should make the investment in domestic fuelcycle facilities superfluous, could be provided by a range of instruments, ranging from legal guarantees to physical stocks of nuclear material to the establishment of multilateral enrichment facilities. ${ }^{68}$

European efforts to develop equitable models for nuclear fuel supply were in line with the thinking of the IAEA Director General. Mohamed ElBaradei supported tighter controls over ENR nuclear technologies but promoted an inclusive approach by arguing that enrichment and reprocessing activities should be restricted "exclusively to facilities under multinational control." ${ }^{69}$ ElBaradei set-up an international expert group, in which Europeans actively engaged to develop and promote MNA concepts. ${ }^{70}$ The report of that group provided the basis for a range of national proposals on MNAs that were advanced on the sidelines of an IAEA-sponsored special conference in September $2006{ }^{71}$

Four of the six commercial suppliers of nuclear fuel come from EU member states and it thus not surprising that these states drove the debate on MNAs forward. Initially, the European fuel suppliers France, Germany, Netherlands, and the United Kingdom joined the United States and Russia in one of the earliest official MNA proposals tabled after George W. Bush's 2004 speech. In the so-called Six Nation Proposal the countries that among themselves divide the market for nuclear fuel supply offered nuclear fuel assurances under a number of conditions, including that the receiving state "has chosen to obtain supplies on the international market and not to pursue sensitive fuel cycle activities." 72

\footnotetext{
${ }^{67}$ Quoted in Boese, Wade: "U.S. Nuclear Trade Restriction Initiatives Still on Hold", Arms Control Today, vol. 34, no. 10 (December 2004), p. 19.

${ }^{68}$ For an overview see Meier, Oliver: "The Growing Nuclear Fuel-Cycle Debate", Arms Control Today, Vol. 36, No. 9, pp. 40-44, at http://www.armscontrol.org/act/2006_11/NAFuel.

${ }^{69}$ ElBaradei, Mohamed: "Towards a safer world," The Economist, (18 October 2003), pp. 43-44.

70 See Müller, Harald: "How to make MNA acceptable?", in: Swoboda, Hannes (ed.) (2009): Peace and disarmament: A world without nuclear weapons? Bruxelles: PSE, pp. 113-116.

${ }^{71}$ IAEA (2005): Multilateral Approaches to the Nuclear Fuel Cycle: Expert Group Report to the Director General of the IAEA. Vienna, International Atomic Energy Agency. For an overview see also Yudin, Yury (2009): Multilateralization of the nuclear fuel cycle: Assessing the existing proposals. New York and Geneva: United Nations, United Nations Publications.

${ }^{72}$ IAEA: "Communication dated 31 May 2006 received from the Permanent Missions of France, Germany, the Netherlands, the Russian Federation, the United Kingdom of Great Britain and Northern Ireland and the United States of America", ( GOV/INF/2006/10), Vienna, International Atomic Energy Agency, (1 June 2006), p. 3.
} 
This proposal, however, turned out to be counterproductive. Many countries which did not operate fuel cycle facilities viewed a commitment to forego fuel-cycle activities as a precondition for access to fuel-supply guarantees as unacceptable and discriminatory. ThenIAEA Director General Mohamed ElBaradei wrote later that the six-country proposal "poisoned the well" because it "only exacerbated the nuclear divide." Reflecting the view of many developing countries, ElBaradei said that proponents of the six-country papers appeared to say "essentially, we keep the technology, and no one else gets it. It was an in-your-face mandate, a blunt demand for participating countries to give up a cherished right."73

Europeans (and later the United States) quickly backtracked. None of the proposals made subsequently repeated the condition that recipient states would have to forego their right to enrichment or reprocessing. In September 2007, the three states operating Urenco issued a joint statement (“Almelo Declaration”) which stated:

"We understand that countries do not wish to renounce the possibility of developing fuel cycle activities. We do not ask them to do so". ${ }^{74}$

The MNA debate also revealed important differences among EU members on the right approach to preventing the spread of ENR technology. Those EU states that had decided domestically to phase out nuclear energy - Austria and Germany - were the ones to offer the most inclusive fuel supply models. During 2006 and 2007, three EU states introduced their own proposals into the debate.

The United Kingdom proposed "enrichment bonds", which would involve binding agreements between supplier and recipient to guarantee the supply of nuclear fuel, "subject to compliance with international law and to meeting the nonproliferation commitments to be assessed by the IAEA."75

The German government proposed to create a new enrichment facility (or facilities) that would be owned and operated by recipient states without giving them access to enrichment technologies ("Multilateral Enrichment Sanctuary Project"). ${ }^{76}$

- Austria submitted a "Food for Thought" paper which proposed to emulate EURATOM on a global level. Austria argued that in a phased manner, all sensitive nuclear activities should be placed under international control, so that eventually "all nuclear fuel would be supplied exclusively via multilateral facilities and institutions.",77

\footnotetext{
73 El Baradei, Mohamed (2011): The age of deception: Nuclear diplomacy in treacherous times. London, Bloomsbury, pp. 124-125.

${ }^{74}$ IAEA: "Communication received from the Resident Representatives of Germany, the Netherlands and the United Kingdom to the Agency concerning multilateral cooperation on energy security in support of Article IV of the Treaty on the Non-Proliferation", (INFCIRC/713), Vienna: International Atomic Energy Agency, 18 September 2007.

75 IAEA: "Communication dated 30 May 2007 from the Permanent Mission of the United Kingdom of Great Britain and Northern Ireland to the IAEA concerning Enrichment Bonds - A Voluntary Scheme for Reliable Access to Nuclear Fuel", (INFCIRC/707), Vienna: International Atomic Energy Agency, 4 June 2007.

${ }^{76}$ IAEA: "Communication received from the Resident Representative of Germany to the IAEA with regard to the German proposal on the Multilateralization of the Nuclear Fuel Cycle", (INFCIRC/704), Vienna, International Atomic Energy Agency, 4 May 2007.

${ }^{77}$ IAEA: "Communication received from the Federal Minister for European and International Affairs of Austria with regard to the Austrian proposal on the Multilateralization of the Nuclear Fuel Cycle", (INFCIRC/706), Vienna, International Atomic Energy Agency, 31 May 2007.
} 
While those EU states actively promoted their different concepts for nuclear fuel guarantees, the EU itself remained passive. In 2007, the EU did merely agree on four criteria that should guide discussions on MNAs. These were:

\author{
- $\quad$ Proliferation resistance, \\ - $\quad$ Assurance of supply, including a predetermined and transparent decision- \\ making mechanism and reliable guarantees for delivery, \\ - Consistency with the equal rights and obligations paradigm, \\ - $\quad$ Market neutrality, both in the sense of not interfering with a functioning market \\ and in maintaining a level playing field between various sources of energy. ${ }^{78}$
}

These principles were, however, too vague to make it possible to discern a unique European position on MNAs. The EU itself did to move the debate forward and has not been able to evolve its position significantly. ${ }^{79}$

In practical terms, the EU was able to influence agreements on MNAs in two instances. The EU did provide financial support by donating Euro 25 million for the nuclear fuel bank supported by a U.S. non-governmental organization, the Nuclear Threat Initiative. ${ }^{80}$ The British proposal on enrichment bonds is one of four concepts to strengthen nuclear fuel assurances that has been approved and/or implemented since George W. Bush have revived the MNA debate in $2004 .^{81}$

\title{
5. Conclusions
}

This cursory review shows that European efforts to control ENR technologies suffer from the same lack of coherence that affects European non-proliferation policies more generally. The fragmented nature of European efforts to control ENR technologies has many reasons. Neither the ESS nor the EU's WMD strategy single better controls on trade in ENR technology out as a key objective. EU efforts to tackle non-proliferation issues such as ENR controls are spread across a range of issue areas, undertaken by a range of actors with different, sometimes competing interests. ${ }^{82}$

\footnotetext{
78 "Multilateralization of the nuclear fuel cycle/guarantees of access to the peaceful uses of nuclear energy: Working paper submitted by the European Union", (NPT/CONF.2010/PC.I/WP.61), Preparatory Committee for the 2010 Review Conference of the Parties to the Treaty on the Non-Proliferation of Nuclear Weapons 2007. Vienna, 9 May 2007.

${ }^{79}$ In the context of the 2010 NPT review conference, the EU repeated that the four principles should guide future discussion on MNAs by stating that it remains "firmly convinced of the benefits of multilateral approaches to the nuclear fuel cycle, in which assurance mechanisms, singly or in conjunction with other complementary mechanisms, should not act to distort the existing well-functioning market, and should address the right of peaceful uses of nuclear energy by providing nuclear fuel supply security for countries developing a nuclear programme in the best safety, security and non-proliferation conditions ..." See Council of the European Union, "Council Decision 2010/212/CFSP of 29 March 2010", op. cit., paragraph 54.

${ }^{80}$ European Council: "Council Conclusions on EU contribution for the establishment of an IAEA nuclear fuel bank", 2914th General Affairs Council meeting, Brussels, 8 December 2008.

${ }^{81}$ The other ideas that have been realized are the U.S. proposal to establish a strategic reserve of highly-enriched uranium that could be blended down as nuclear fuel; a reserve of 120 tons of low-enriched uranium in Russia and the NTI proposal to establish a similar reserve of LEU. See McGoldrick, "Limiting Transfer of Enrichment...", op. cit., p. 3.

${ }^{82}$ See for example Zwolski, Kamil: “The External Dimension of the EU's Non-proliferation Policy: Overcoming Inter-institutional Competition”, European Foreign Affairs Review, vol. 16, no. 3 (2011), pp. 325-340.
} 


\begin{abstract}
"Although the strategies framed WMD non-proliferation as a horizontal issue within the CFSP and sought to integrate non-proliferation policy with external relations (namely trade and development cooperation), few links were made between the new external non-proliferation policy and existing internal policies on chemical, biological, radiological and nuclear (CBRN) threat mitigation. ${ }^{183}$
\end{abstract}

Another reason for the lack of coherence of the EU's non-proliferation policy is the fact that "the WMD Strategy is not an official 'common strategy', but little more than a political declaration without an established policy framework and earmarked (financial) resources." 84

As a result, efforts to prevent the spread of ENR technologies were driven by EU members but less by the EU itself. Europe's leading role in negotiations with Iran was the result of the initiative of the EU3, rather than a concerted effort by all EU members. The EU was also not able to articulate common proposal to take the debate on multilateral nuclear approaches forward, even though Europeans were in a unique position to promote such concepts because the only two multilateral enrichment facilities - Areva and Urenco - are operated in Europe. Instead, EU members individually made a number of proposals that sometimes had a different political thrust. Proposals came particularly from those EU members that have economic interests in the international nuclear fuel market and were heavily influenced by national preferences on the use of nuclear energy more generally. ${ }^{85}$ The EU does not act as a bloc in the NSG, yet the highly integrated European policy on export controls did lead to Europeans to pursue similar policies on strengthening ENR guidelines. Yet, as the example of France's interpretation of the NSG's new ENR guidelines demonstrated, economic interest can still undermine EU unity.

Generally speaking, the EU performance in controlling ENR technologies was strongest when it could mediate between two extreme positions. Thus, Europeans were quite successful in defining the middle ground between Iran or the non-aligned movement on the one side and the George W. Bush administration on the other side. Vice versa, Europeans appeared to be happy to concede leadership on Iran's nuclear file to the United States, once the Obama administration reverted to a more moderate approach on non-proliferation.

Because of the EU's inherent difficulties of providing international leadership on highprofile issues, the EU now appears to focus on improving implementation of existing nonproliferation rules, regulations and agreements. Many of the EU's activities today are related to improved export controls or providing assistance to third states to strengthen national implementation of non-proliferation obligations. The EU also is good at providing financial and other practical support for organizations and arrangements involved in arms control and non-proliferation. These are important activities but by themselves they do not drive the disarmament, arms control and non-proliferation agenda forward.

Institutional impediments to a more effective EU non-proliferation policy can be overcome if there is sufficient political will and leadership. Yet, developing a forward-looking agenda cannot be expected from EU institutions alone. As Peter van Ham observes:

\footnotetext{
${ }^{83}$ Grip, "Mapping the European Union's institutional actors...", op. cit., p. 2.

${ }^{84}$ Van Ham, “The European Union's WMD Strategy...", op. cit., p. 2.

${ }^{85}$ See Meier, Oliver: “The EU's Nonproliferation Efforts: Limited Success", Arms Control Today, vol. 38, no. 4 (May 2008), pp. 20-26, at http://www.armscontrol.org/act/2008 05/OliverFeature.
} 
"As long as the EU fails to assure that all its institutions - from the Commission and the European Parliament to the Council-work together, the lack of coherence will result in relative ineffectiveness. But the EU has more to do than get its house in order, since member states themselves still have major normative and policy dichotomies. A coherent and effective EU WMD policy is difficult, if not impossible, to establish by the simple fact that the EU comprises nuclear weapon states and non-nuclear weapon states, members of the North Atlantic Treaty Organization (NATO) and non-NATO states, and supporters and opponents of nuclear energy. Despite the EU's efforts to strengthen its own role on nonproliferation matters, its WMD policy remains capital-based with national experts and representatives from member states playing a key role." 86

Realistically, the ultimate responsibility for developing a coherent and forward-looking agenda for issues such as better controls on ENR technologies therefore still rests with EU member states, particularly those that have access to such technologies. It is to be hoped that this challenge motivates Europeans to overcome the political, institutional and bureaucratic hurdles that stand in the way of a more unified EU policy on important issues that as better controls on ENR technologies. One thing is clear: an EU acting together will have more influence than any combination of its member states acting in concert.

\footnotetext{
${ }^{86}$ Van Ham, “The European Union's WMD Strategy...", op. cit., pp. 5-6.
} 